\title{
TEH BUBUK HERBAL DAUN ASHITABA DAN KULIT BUAH NAGA
}

\author{
Syirril Ihromi ${ }^{*}$, AsmawatI ${ }^{2}$, Earlyna Sinthia Dewi ${ }^{3}$, Muliatiningsih $^{4}$ \\ 1,2 \&3Teknologi Hasil Pertanian, Universitas Muhammadiyah Mataram, syirrilihromi@ummat.ac.id. \\ ${ }^{4}$ Teknik Pertanian, Universitas Muhammadiyah Mataram
}

\begin{tabular}{l} 
INFO ARTIKEL \\
\hline RiwayatArtikel: \\
Diterima: 01-07-2019 \\
Disetujui: 11-08-2019
\end{tabular}

\section{Kata Kunci:}

Formulasi

Daun ashitaba

Kulit buah naga

Teh herbal

\begin{abstract}
ABSTRAK
Abstrak: Ashitaba (Angelica keiskel) merupakan salah satu tanaman introduksi yang berpotensi meningkatkan produksi sel darah merah, produksi hormon pertumbuhan serta meningkatkan pertahanan tubuh untuk melawan infeksi, kanker dan juga sebagai sumber antioksidan. Selain daun ashitaba bahan potensial untuk dikembangkan menjadi teh herbal adalah kulit buah naga yang kaya polyphenol dan sumber antioksidan. Penelitian ini bertujuan untuk mengetahui formulasi daun ashitaba dan kulit buah naga merah yang tepat dan mengetahui pengaruh formulasi daun ashitaba dan kulit buah naga merah terhadap sifat kimia dan organoleptik teh bubuk herbal. Adapun formulasi perlakuan yaitu; perlakuan 1 (daun ashitaba 0\%:kulit buah naga merah100\%), 2 (daun ashitaba 25\%: kulit buah naga merah 75\%), 3 (daun ashitaba 50\% : kulit buah naga merah 50\%), 4 (daun ashitaba 75\% : kulit buah naga merah 25\%) dan 5 (daun ashitaba 100\%: kulit buah naga merah 0\%). Hasil penelitian menunjukkan formulasi daun ashitaba dengan kulit buah naga berpengaruh secara nyata terhadap kadar abu, antioksidan, skor nilai rasa, warna bubuk dan warna seduhan tetapi tidak berpengaruh pada kadar air da skor aroma teh herbal. Perlakuan terbaik didapatkan pada perlakuan P2 (formulasi daun ashitaba 25\% dengan kulit buah naga 75\%) karena menghasilkan teh herbal yang memenuhi standar SNI.
\end{abstract}

\section{A. LATAR BELAKANG}

Ashitaba (Angelica keiskei) merupakan salah satu tanaman introduksi. Tanaman ashitaba dapat tumbuh baik di Kabupaten Lombok Timur Provinsi Nusa Tenggara Barat yang berlokasi di Desa Sembalum. Perbanyakan ashitaba cukup dengan menggunakan biji yang dihasilkan dari tanaman yang telah berumur 3-4 tahun, dengan cara melakukan penyemaian biji. Tanaman ashitaba berpotensi meningkatkan produksi sel darah merah, produksi hormon pertumbuhan serta meningkatkan pertahanan tubuh untuk melawan infeksi, kanker dan juga sebagai sumber antioksidan [1]. Tanaman ashitaba kaya akan betakaroten, vitamin B1, B2, B3, B5, B6, B12, biotin, asam folik dan vitamin C, dan juga mengandung beberapa mineral seperti kalsium, magnesium, potasium, fosfor, seng dan tembaga [2]. Selain itu tanaman ini berpotensi sebagai obat karena dari getahnya yang berwarna kuning mengandung suatu zat yaitu chalcone [3]. Zat aktif yang terdapat dalam chalcone bermanfaat untuk meningkatkan produksi sel darah merah, meningkatkan daya konsentrasi, produksi hormon pertumbuhan serta meningkatkan pertahanan tubuh untuk melawan penyakit infeksi [4]. Selama ini ashitaba diolah menjadi sayur dan dijadikan teh dengan cara diseduh sehingga lebih praktis.

Selain daun ashitaba bahan potensial untuk dikembangkan menjadi teh adalah kulit buah naga. Kulit buah naga merah kaya polyphenol dan sumber antioksidan yang baik [5]. Menurut [6] ekstrak kulit buah naga merah dengan pelarut air mengandung $1,1 \mathrm{mg} / 100$ $\mathrm{ml}$ antosianin, dimana antosianin dapat berfungsi untuk menurunkan kadar kolestrol dalam darah, sehingga kulit buah naga merah dapat dimanfaatkan untuk pembuatan teh instan. Selama ini kulit buah naga belum banyak dimanfaatkan sebagai produk olahan pangan.

Produk pangan yang dikehendaki oleh masyarakat modern tidak hanya mempertimbangkan unsur pemenuhan gizi, akan tetapi juga harus praktis, cepat saji, tahan lama dan tidak memerlukan tempat atau ruang penyimpanan yang lebih besar. Produk pangan bubuk siap saji (teh bubuk) merupakan produk pangan yang berbentuk bubuk, berstruktur remah, mudah dilarutkan dengan air dingin maupun air panas, mudah dalam penyajian, mudah terdispersi dan tidak mengendap dibagian bawah wadah [7], [8]. Salah satu alternatif pemanfaatan daun ashitaba dan kulit buah naga merah dalam bentuk lain adalah dalam bentuk teh instan. Teh instan merupakan produk padat berbentuk partikel halus yang sangat kering, yang dihasilkan dari 
pengeringan sari daun atau bubur kulit buah dengan atau tanpa bahan tambahan, yang proses pengurangan airnya berjalan cepat dengan pengeringan, pengeringan beku, atau dengan pengeringan drum. Bahan tambahan yang sering dipakai diantaranya adalah, pati jagung, kacang-kacangan, vitamin, mineral, zat pengawet dan gula [9]. [10] juga menyatakan bahwa dengan membuat produk pangan bubuk instan, kendala dan masalah penyimpanan serta transportasi makin dipermudah.

Cara pembuatan teh bubuk instan menurut [11] pada minuman instan jahe meliputi tahapan-tahapan yakni dimulai dari pemilihan bahan, pencucian, pengirisan, perebusan, penghancuran, penyaringan, kemudian sari yang dihasilkan ditambahkan gula, proses kristalisasi, pemblendearan kristal dan pengayakan.

Bahan tambahan yang sering dipakai dalam pembuatan bubuk instan adalah gula. Gula adalah suatu karbohidrat sederhana yang menjadi sumber energi dan komoditi perdagangan utama. Gula paling banyak diperdagangkan dalam bentuk kristal sukrosa padat. Selain memberikan rasa manis pada saat rehidrasi, gula juga mencegah pertumbuhan mikroba sehingga dapat digunakan sebagai bahan pengawet karena bersifat higroskopis atau menyerap air [9]. Menurut [12], Penambahan gula sebanyak $150 \mathrm{~g} / \mathrm{l}$ pada pembuatan sari buah mampu memberikan flavor dan rasa yang enak. Sedangkan menurut [13] bahwa kosentrasi penambahan gula pada kisaran 20-50 \% mampu mencegah kerusakan akibat mikroba.

Berdasarkan uraian latar belakang tersebut maka penelitian ini bertujuan untuk mengetahui formulasi daun ashitaba dan kulit buah naga merah yang tepat dan mengetahui pengaruh formulasi daun ashitaba dan kulit buah naga merah terhadap sifat kimia dan organoleptik teh bubuk herbal.

\section{B. METODE PENELITIAN}

\section{Rancangan Penelitian}

Penelitian dirancang dengan Rancangan Acak Lengkap [14] dan perlakuan formulasi daun ashitaba dengan kulit buah naga dilakukan dalam 5 aras perlakuan dengan 3 kali ulangan sehingga diperoleh 15 unit percobaan. Pendenahan dalam rancangan penelitian dapat dilihat pada Tabel 1.

\section{Tabel 1}

Pendenahan Dalam Rancangan Percobaan

\begin{tabular}{|c|c|c|c|c|c|}
\hline \multirow[b]{2}{*}{ Ulangan } & \multicolumn{5}{|c|}{$\begin{array}{c}\text { Taraf Perlakuan (\%) } \\
\text { Daun ashitaba : kulit buah naga merah }\end{array}$} \\
\hline & $\begin{array}{c}\text { o: } \\
\text { 100 }\end{array}$ & $25: 75$ & $\begin{array}{c}50: \\
50\end{array}$ & $75: 25$ & $\begin{array}{c}100: \\
0\end{array}$ \\
\hline 1 & & & $\mathrm{P} 2 \mathrm{UI}$ & & $\mathrm{P}_{5} \mathrm{U}_{1}$ \\
\hline 2 & & & & & \\
\hline 3 & $\mathrm{P}_{1} \mathrm{U}_{3}$ & $\mathrm{P}_{2} \mathrm{U}_{3}$ & $\mathrm{P}_{3} \mathrm{U}_{3}$ & $\mathrm{P}_{4} \mathrm{U}_{3}$ & $\mathrm{P}_{5} \mathrm{U}_{3}$ \\
\hline
\end{tabular}

Keterangan :

$\mathrm{P}=$ Formulasi daun ashitaba dengan kulit buah nagas

$\mathrm{U}=$ ulangan ke 1, 2, 3

Data dianalisis menggunakan analisis keragaman pada taraf $5 \%$. Apabila hasil analisis ragam berpengaruh nyata, maka dilakukan uji lanjut dengan uji BNJ pada taraf nyata $5 \%$.

\section{Parameter Penelitian}

Parameter yang diamati dalam penelitian meliputi uji kimia dan organoleptik. Uji kimia yang dilakukan yaitu penentuan kadar air, kadar abu dan kadar antioksidan menggunakan pengujian berdasarkan [15]. Sedangkan uji organoleptik meliputi warna, rasa, dan aroma menggunakan pengujian berdasarkan [16].

\section{Tempat Penelitian}

Penelitian dilaksanakan di laboratorium Pengolahan Hasil Pertanian dan Laboratorium Kimia Fakultas Pertanian Universitas Muhammadiyah Mataram.

\section{Tahapan Penelitian}

Tahapan penelitian diawali dengan penyiapan bahan baku dan bahan pendukung lainnya untuk pembuatan teh herbal. Pembuatan bubuk teh herbal dapat dilihat pada gambar 1.

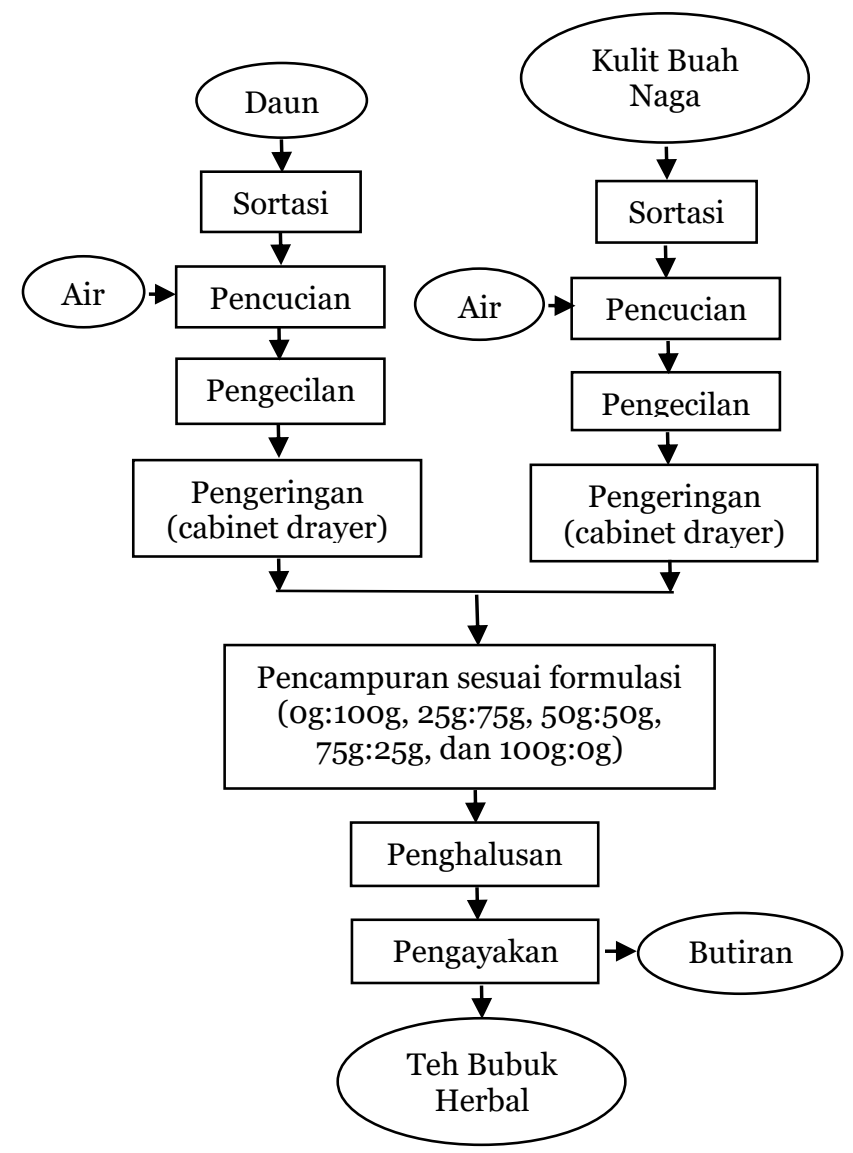

Gambar 1. Diagram Alir Proses Pembuatan Teh Bubuk Herbal (Modifikasi Penelitian [17]).

\section{HASIL DAN PEMBAHASAN}

\section{Hasil Penelitian}

Hasil penelitian dan analisis keragaman berikut uji lanjut untuk parameter sifat kimia dan sifat organoleptik dapat dilihat pada tabel 2 . 
Tabel 2.

Purata Hasil Formulasi Daun Ashitaba Dan Kulit Buah Naga Terhadap Beberapa Komponen Mutu Teh Herbal

\begin{tabular}{cllllll}
\hline Parameter & \multicolumn{5}{c}{ Perlakuan } & \multirow{2}{*}{ BNJ } \\
\cline { 2 - 5 } & P1 & P2 & P3 & P4 & P5 & - \\
Sifat Kimia & & & & & \\
Kadar Air & 10.62 & 11.41 & 12.13 & 12.58 & 12.35 & 1,72 \\
Kadar Abu & $12.22 \mathrm{ab}$ & $13.83 \mathrm{bc}$ & $14.17 \mathrm{c}$ & $13.32 \mathrm{bc}$ & $11.85 \mathrm{a}$ & 2,61 \\
Kadar Antioksidan & $85.43 \mathrm{c}$ & $84.50 \mathrm{c}$ & $80.28 \mathrm{~b}$ & $76.29 \mathrm{a}$ & $74.00 \mathrm{a}$ & \\
Sifat Organoleptik & & & & & & \\
Warna Bubuk & $1.85 \mathrm{~b}$ & $1.20 \mathrm{a}$ & $3.10 \mathrm{c}$ & $4.45 \mathrm{~d}$ & $5.00 \mathrm{~d}$ & 0,92 \\
Warna Seduhan & $1.95 \mathrm{a}$ & $1.20 \mathrm{a}$ & $3.00 \mathrm{~b}$ & $3.40 \mathrm{bc}$ & $4.15 \mathrm{c}$ & - \\
$\quad$ Aroma & 2.90 & 2.90 & 2.80 & 3.10 & 2.95 & 0,93 \\
Rasa & $3.40 \mathrm{~b}$ & $3.40 \mathrm{~b}$ & $3.30 \mathrm{ab}$ & $2.40 \mathrm{a}$ & $3.15 \mathrm{ab}$ & \\
\hline
\end{tabular}

Keterangan : Angka-angka yang diikuti oleh huruf yang sama pada baris yang sama tidak berbeda nyata pada taraf $5 \%$

\section{Pembahasan}

\section{a. Kadar Air}

Berdasarkan hasil analisis keragaman pada parameter kadar air menunjukkan bahwa semakin tinggi formulasi penggunaan daun ashitaba dalam pembuatan teh herbal maka kadar air cendrung meningkat, namun tidak berbeda nyata setiap perlakuan seperti terlihat pada gambar 2 .

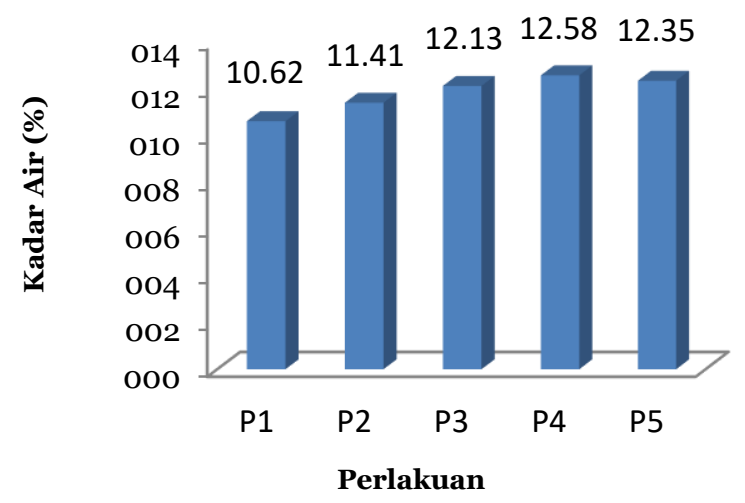

Gambar 2. Grafik hubungan formulasi daun ashitaba dan kulit buah naga terhadap kadar air teh herbal

Kadar air teh herbal berkisar antara 10,62\% sampai $12,62 \%$ namun dari hasil uji statistik tidak berpengaruh nyata, hal ini dikarenakan tingkat kekeringan dari daun ashitaba dan kulit buah naga yang digunakan hampir sama, karena kedua bahan dikeringkan dengan suhu yang sama yaitu $60^{\circ} \mathrm{C}$. Selama proses pengeringan bahan terjadi pengurangan kadar air bahan dimana air di dalam bahan akan keluar dan menguap akibat proses pengeringan menggunakan suhu diatas $50^{\circ} \mathrm{C}$ sehingga bahan menjadi kering. Kandungan air dalam bahan pangan ikut menentukan acceptability, kesegaran dan daya tahan dan simpan bahan itu sendiri [7].

Berdasarkan Standar mutu teh herbal SNI 03-3836-2012 menunjukkan bahwa kadar air teh herbal yang dihasilkan sudah memenuhi syarat dimana syarat mutu teh berkisar antara $8-14 \%$.

\section{b. Kadar Abu}

Berdasarkan hasil analisis keragaman pada parameter kadar abu menunjukkan bahwa semakin tinggi formulasi penggunaan daun ashitaba dalam pembuatan teh herbal maka kadar abu cendrung semakin meningkat, seperti terlihat pada gambar 3 .

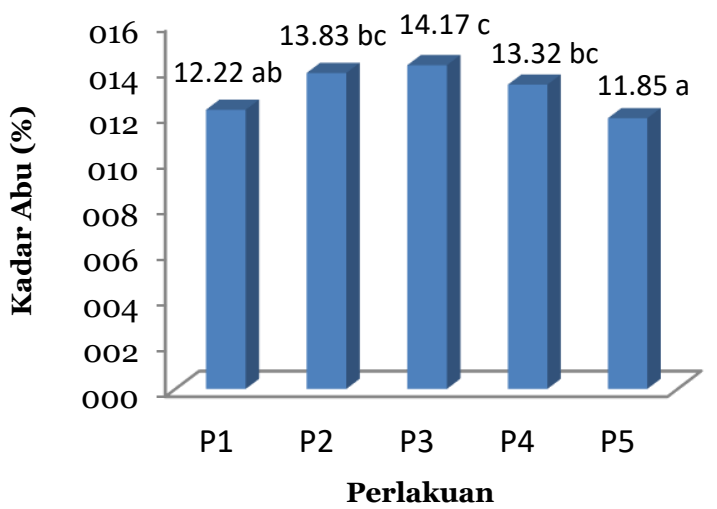

Gambar 3. Grafik hubungan formulasi daun ashitaba dan kulit buah naga terhadap kadar abu teh herbal

Abu adalah zat anorganik sisa hasil pembakaran suatu bahan organik. Kadar abu dilakukan dengan cara mengoksidasikan bahan pada suhu yang tinggi yaitu sekitar 500 $600^{\circ} \mathrm{C}$ kemudian melakukan penimbangan zat yang tertinggal setelah proses pembakaran tersebut [15].

Berdasarkan hasil analisis keragaman kadar abu teh herbal menunjukkan bahwa kadar abu tertinggi diperoleh pada perlakuan $\mathrm{P}_{3}$ (formulasi daun ashitaba 50\% dengan kulit buah naga 50\%) yaitu sebesar $14,17 \%$. Tingginya kadar abu pada perlakuan $\mathrm{P}_{3}$ disebabkan karena adanya kandungan mineral yang ada pada daun ashitaba. Adapun mineral dalam daun ashitaba yaitu potassium, calcium, sodium, kalium, besi, fosfor, seng, tembaga dan 
magnesium [2]. Kadar abu dipengaruhi oleh suhu selama pengeringan (oven) yang mempengaruhi kadar air dalam bahan menguap sehingga kadar air cenderung menurun maka kadar mineral pada bahan yang merupakan komponen penyusun kadar abu cenderung meningkat. Hal ini didukung oleh pendapat [18], yang menyatakan bahwa suhu yang digunakan dalam proses pengeringan (oven) akan menurunkan kadar air sehingga akan meningkatkan komponen penyusun kadar abu.

Berdasarkan Standar mutu teh herbal SNI 03-3836-2012 menunjukkan bahwa kadar abu teh herbal yang dihasilkan sudah memenuhi syarat dimana syarat mutu teh berkisar antara 8-14\%.

\section{c. Kadar Antioksidan}

Berdasarkan hasil analisis keragaman pada parameter kadar antioksidan menunjukkan bahwa semakin tinggi formulasi penggunaan kulit buah naga dalam pembuatan teh herbal maka kadar antioksidan cendrung semakin meningkat, seperti terlihat pada gambar 4 .

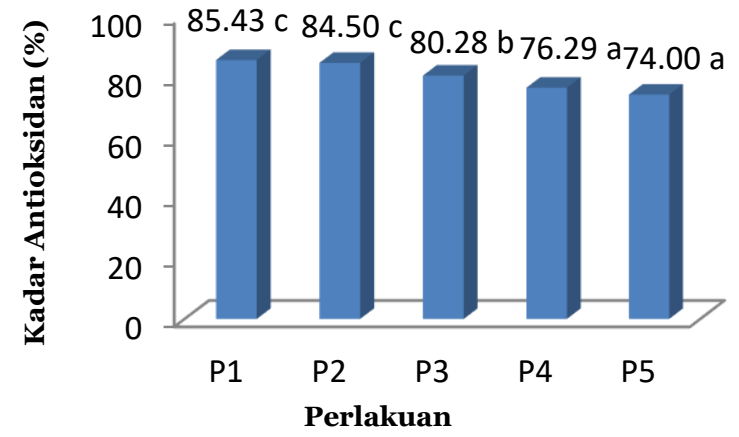

Gambar 4. Grafik hubungan formulasi daun ashitaba dan kulit buah naga terhadap kadar antioksidan teh herbal

Berdasarkan hasil analisis keragaman kadar antioksidan teh herbal menunjukkan bahwa semakin tinggi penggunaan kulit buah naga dalam formulasi maka kadar antioksidan semakin meningkat. Kadar antioksidan tertinggi diperoleh pada perlakuan P1 (formulasi daun ashitaba $0 \%$ dengan kulit buah naga $100 \%$ ) yaitu sebesar $85,425 \%$. Tingginya kadar antioksidan pada perlakuan P1 disebabkan kandungan antioksidan dalam kulit buah naga yang lebih tinggi dibandingkan yang terdapat pada daun ashitaba. Ha ini sesuai dengan pendapat [19] yang menyatakan bahwa kulit buah naga mengandung lebih banyak senyawa yang berperan sebagai antioksidan seperti niasin, riboflamin, antosianin, fitoalbumin, karotenoid, vitamin $\mathrm{C}$ dan tiamin, sedangkan daun ashitaba mengandung betakaroten, vitamin B1, B2, B3, B5, B6, B12, biotin, asam folik dan vitamin $\mathrm{C}$, serta beberapa mineral seperti kalsium, magnesium, potasium, fosfor, seng dan tembaga [2].

\section{d. Warna Bubuk}

Berdasarkan hasil analisis keragaman terhadap sifat organoleptik warna bubuk menunjukkan formulasi daun ashitaba dengan kuit buah naga pada pembuatan teh herbal berpengaruh secara nyata terhadap tingkat kesukaan panelis terhadap warna teh herbal yang dihasilkan, seperti terlihat pada gambar 5 .

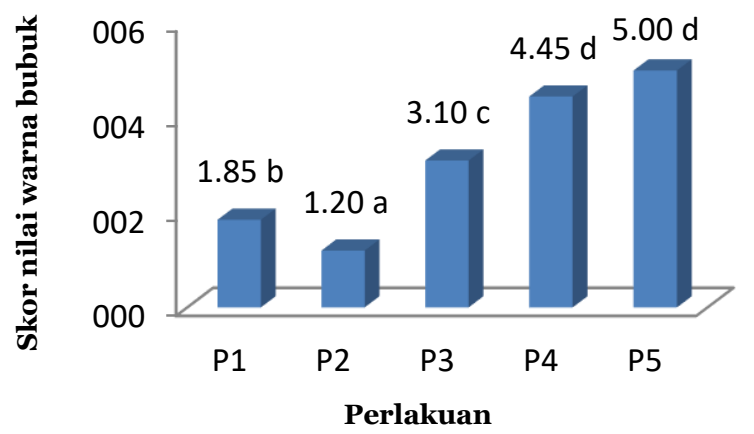

Gambar 5. Grafik hubungan formulasi daun ashitaba dan kulit buah naga terhadap skor nilai warna bubuk teh herbal

Tingkat skor panelis terhadap warna bubuk teh herbal tertinggi diperoleh pada perlakuan $\mathrm{P}_{5}$ (formulasi daun ashitaba 100\% dengan kulit buah naga $0 \%$ ) sebesar 5,00 dengan kriteria berwarna hijau dan skor terendah diperoleh pada perlakuan P2 (formulasi daun ashitaba $25 \%$ dengan kulit buah naga $75 \%$ ) sebesar 1,20 dengan kriteria warna ungu tua. Penggunaan campuran antara daun ashitaba dengan kuit buah naga menyebabkan terjadinya perbedaan warna teh herbal yang dihasilkan dimana terjadi degradasi warna dari ungu tua sampai hijau. Ketika penggunaan kulit buah naga yang semakin meningkat maka akan berwarna ungu namun sebaliknya ketika penggunaan daun ashitaba yang semakin tinggi maka akan berwarna hijau, dengan kata lain produk yang dihasilkan dipengaruhi oleh warna dasar dari bahan baku. Warna sangat berpengaruh terhadap kualitas bahan pangan, karena merupakan salah satu penilaian terhadap mutu bahan pangan tersebut. Hal ini sesuai dengan pendapat [18], bahwa penentuan mutu suatu bahan pangan pada umumnya tergantung pada warna, karena warna tampil terlebih dahulu dan dapat menentukan mutu dari bahan pangan tersebut.

\section{e. Warna Seduhan}

Berdasarkan hasil analisis keragaman terhadap sifat organoleptik warna seduhan menunjukkan bahwa perlakuan formuasi daun 
ashitaba dengan kuit buah naga pada pembuatan teh herbal berpengaruh secara nyata terhadap tingkat kesukaan panelis terhadap warna seduhan teh herbal yang dihasilkan, seperti terlihat pada gambar 6 .

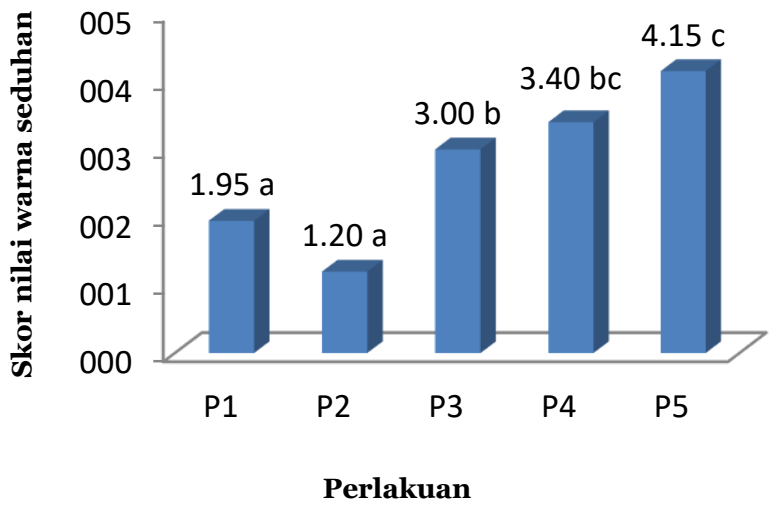

Gambar 6. Grafik hubungan formulasi daun ashitaba dan kulit buah naga terhadap skor nilai warna seduhan teh herbal

Tingkat skor panelis terhadap warna seduhan teh herbal tertinggi diperoleh pada perlakuan $\mathrm{P}_{5}$ (formulasi daun ashitaba $100 \%$ dengan kulit buah naga $0 \%$ ) sebesar 4,00 dengan kriteria berwarna hijau muda dan skor terendah diperoleh pada perlakuan P2 (formulasi daun ashitaba 25\% dengan kulit buah naga $75 \%$ ) sebesar 1,20 dengan kriteria warna unggu tua. Penggunaan campuran antara daun ashitaba dengan kulit buah naga menyebabkan terjadinya perbedaan warna seduhan dari teh herbal yang dihasilkan dimana terjadi degradasi warna dari unggu tua sampai berwarna hijau. Ketika penggunaan kulit buah naga yang semakin meningkat maka akan berwarna ungu namun sebaliknya ketika penggunaan daun ashitaba yang semakin tinggi maka akan berwarna hijau, dengan kata lain produk yang dihasilkan dipengaruhi oleh warna dasar dari bahan baku. Warna sangat berpengaruh terhadap kualitas bahan pangan, karena merupakan salah satu penilaian terhadap mutu bahan pangan tersebut. Hal ini sesuai dengan pendapat [18], bahwa penentuan mutu suatu bahan pangan pada umumnya tergantung pada warna, karena warna tampil terlebih dahulu dan kadang-kadang menentukan mutu dari bahan pangan.

\section{f. Aroma}

Berdasarkan hasil analisis keragaman terhadap sifat organoleptik aroma menunjukkan bahwa perlakuan formuasi daun ashitaba dengan kulit buah naga pada pembuatan teh herbal tidak berpengaruh secara nyata terhadap tingkat kesukaan panelis terhadap aroma teh herbal yang dihasilkan, seperti terlihat pada gambar 7 .

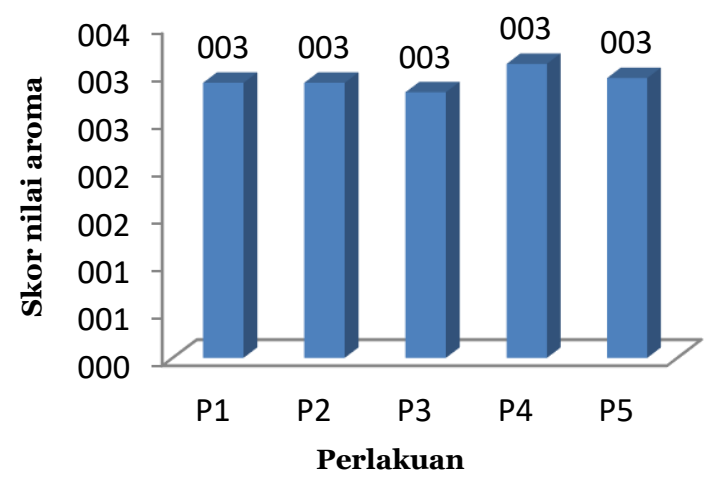

Gambar 7. Grafik hubungan formuasi daun ashitaba dan kulit buah naga terhadap skor nilai aroma teh herbal

Dari hasil penelitian menunjukkan bahwa Uji hedonik terhadap aroma teh herbal diperoleh tingkat kesukaan panelis dengan kisaran skor dari 2,80-3,10 dengan kriteria agak suka. Hasil analisa ragam menunjukkan bahwa formulasi daun ashitaba dengan kulit buah naga tidak berbeda nyata terhadap aroma teh herbal. Hal ini dipengaruhi oleh aroma dari daun ashitaba maupun kulit buah naga yang samasama beraroma khas, dimana panelis lebih suka pada perakuan $\mathrm{P}_{4}$ dengan formuasi daun ashitaba $75 \%$ dengan kuit buah naga 25\%. Pada umumnya aroma produk makanan dibentuk oleh bahan penyusun. Perlakuan selama proses pembuatan, terutama suhu tinggi pada pengukusan, perebusan dan penjemuran dapat menyebabkan flavor berkurang. Kerugian utama dari dehidrasi salah satunya adalah hilangnya flavor yang mudah menguap [20].

\section{g. Rasa}

Berdasarkan hasil analisis keragaman terhadap sifat organoleptik rasa menunjukkan bahwa perlakuan formuasi daun ashitaba dengan kulit buah naga pada pembuatan teh herbal berpengaruh secara nyata terhadap tingkat kesukaan panelis terhadap rasa teh herbal yang dihasilkan, seperti terlihat pada gambar 8.

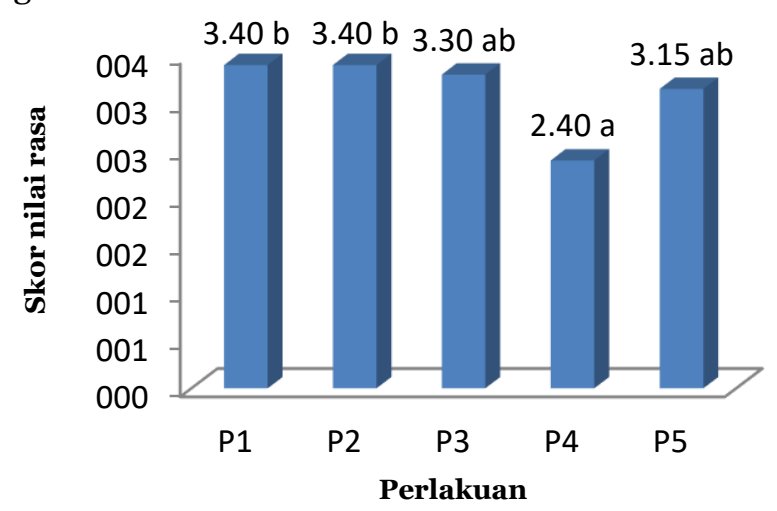


Gambar 8. Grafik hubungan formuasi daun ashitaba dan kulit buah naga terhadap skor nilai rasa teh herbal

Dari hasil penelitian menunjukkan bahwa tingkat kesukaan panelis terhadap rasa teh herbal tertinggi diperoleh pada perlakuan P1 dan P2 (formuasi daun ashitaba $0 \%$ dengan kulit buah naga 100\%) dan (formuasi daun ashitaba $25 \%$ dengan kulit buah naga $75 \%$ ) sebesar 3,40 dengan krieria suka dan tingkat kesukaan terendah diperoleh pada perlakuan P4 (formuasi daun ashitaba $75 \%$ dengan kulit buah naga 25\%) sebesar 2,40 dengan kriteria tidak suka. Tingkat kesukaan terhadap rasa teh herbal disebabkan pada perlakuan P1 dan P2 lebih dominan mengandung kulit buah naga dimana didalam kuit buah naga masih mengandung senyawa gula yang mempunyai rasa. Rasa pada seduhan teh merupakan kombinasi cita rasa dan aroma yang dibuat untuk memenuhi selera konsumen. Rasa lebih banyak melibatkan panca indera lidah. Rasa makanan dapat dikenali oleh kuncup-kuncup cecapan yang terletak pada papila. Penginderaan cecapan dapat merasakan empat jenis cecapan yaitu, asin, asam, manis dan pahit. Rasa manis pada seduhan teh ditimbulkan oleh senyawa organik alifatik yang mengandung gugus $\mathrm{OH}[18]$.

\section{SIMPULAN DAN SARAN SIMPULAN}

1. Pada sifat kimia perlakuan formulasi daun ashitaba dengan kulit buah naga berpengaruh secara nyata terhadap kadar abu dan antioksidan, tetapi tidak berpengaruh pada kadar air teh herbal.

2. Pada sifat organoleptik perlakuan formulasi daun ashitaba dengan kulit buah naga tidak berpengaruh secara nyata terhadap skor nilai aroma tetapi berpengaruh secara nyata terhadap skor nilai rasa, warna bubuk dan warna seduhan teh herbal yang dihasilkan.

3. Dari sifat kimia dan organoleptik perlakuan terbaik didapatkan pada perlakuan P2 (formulasi daun ashitaba $25 \%$ dengan kulit buah naga $75 \%$ ) karena menghasilkan teh herbal yang memenuhi standar SNI.

\section{SARAN}

1. Untuk membuat teh herbal daun ashitaba dengan kulit buah naga disarankan dengan menggunakan formulasi daun ashitaba $25 \%$ dengan kulit buah naga 75\% karena cenderung lebih disukai panelis.

2. Perlu dilakukan penelitian serupa namun dilakukan analisis yang mendalam terhadap kadar beta karoten, uji aktivitas antioksidan, protein dan kadar serat teh herbal yang dihasilkan, karena kadar tersebut sangat dibutuhkan oleh tubuh manusia.

3. Perlu dilakukan penelitian terhadap berbagai bagian dari daun ashitaba

\section{UCAPAN TERIMA KASIH}

Penulis mengucapkan terima kasih kepada Universitas Muhammadiyah Mataram atas dukungan materil dalam melaksanakan penelitian ini sehingga berjalan dengan lancar dan mendapatkan hasil yang baik.

\section{DAFTAR RUJUKAN}

[1] Ma'mun, Bagem S. Sembiring, F. Manoi, Shinta S., E. Hayani, M. Sukmasari dan Wahyudiono. Laporan Teknis Penelitian, Balai Penelitian Tanaman Obat dan Aromatik. Tidak diterbitkan. 12 hlm. 2009.

[2] Baba, K.. Healthy vegetable as-hitaba. Chikuya Shuubansha. Components and Line Breeding of Angelica keiskei koidzumi", Bunseki Kagaku, Vol.58 No.12, December 1995.

[3] Ogawa, H., Nakamura, R., Baba, K.. "Beneficial effect to laserpitin, a caumarin compound from Angelica keiskei, on lipid metabolism in strokeprone spontaneously hyper-tensive rats". Journal of Clinical and Experimental Pharmacology and Physiology. Kinki University School of Medicine, Osaka, Japan. 32: 11041109. 2005.

[4] Hida, K. Ashitaba. A Medicinal Plant and Health Method.www.Organicasihitaba.com/articles.ht ml. 9 Desember 2009.

[5] Li Chen Wu, Hsiu-Wen Hsu, Yun-Chen Chen, ChihChung Chiu Yu-in Lin and Annie Ho. Antioxidant And Antiproliferative Activites Of Red. 2005.

[6] Saati, Elfi Anis. Identifikasi Dan Uji Kualitas Pigmen Kulit Buah Naga Merah Pada Beberapa Umur Simpan Dengan Perbedaan Jenis Pelarut. Direktorat Penelitian Dan Pengabdian Masyarakat. JIPTUMMDPPM. UMM. Malang. 2009.

[7] Desrosier N. W. Teknologi Pengawetan Pangan. Terjemahan muchi Muljoharjo. Penerbit Universitas Indonesia. Jakarta. 1988.

[8] Wirakartakusuma, K. Abdullah, dan A. Syarif. Sifatsifat Pangan. Departemen Pendidikan dan Kebudayaan. Direktorat Jendral Pendidikan Tinggi.Pusat Antar Universitas pangan dan Gizi. Institut Pertanian Bogor. Bogor. 1992.

[9] Suyitno,T., 1995. Prospek Pengembangan Bubuk Buah Durian Dan Sirsak denganPengeringan Beku. Abstrak. Buletin Teknologi Dan Industri 
Pangan. Fakultas Teknologi Pertanian. UGM. Yogyakarta. 1995.

[10] Hartomo, A.J., dan M.C. Widiatmoko. Emulsi dan Pangan Instant Berlisitin. Andi Offset. Yogyakarta. 1993.

[11] Mulyono. Khasiat dan Manfaat Jahe Merah si Rimpang Ajaib. Agro Media Pustaka. Jakarta. 2002.

[12] Astawan, M., dan M. Wahyuni. Teknologi Pengolahan Pangan Nabati TepatGuna. Akademi Pressindo. Jakarta. 1991.

[13]Muchtadi, T.R.. Teknologi Pengolahan Pangan. Depdikbud. Dirjen Dikti. PAU Pangan dan Gizi. IPB. Bogor. 1989.

[14] Hanafiah K. A., . Rancangan Percobaan, Teori dan Aplikasi. Raja Grafindo Persada, Jakarta. 1994.

[15] Sudarmadji, Haryono dan Suhardi. Prosedur Analisa Bahan Makanan Dan Pertanian. Liberty. Yogyakarta. 1997.

[16]Soekarto. Penilaian Organoleptik. Pusat Pengembangan Teknologi Pangan. Bogor: Institut Pertanian Bogor. 1990.

[17] Suherman Eman. Kajian Sifat Fisik Kimia Dan Organeleptik Instant Nenas Ananas comosus (L.) Merr) Pada Berbagai Konsentrasi Gula Pasir.Skripsi. Universitas Mataram. 2001.

[18] Winarno, F. G. Kimia Pangan dan Gizi. Jakarta: PT. Gramedia Pustaka Utama. 2004.

[19] Pujiharjo, Danank. Kajian Aktivitas Antioksidan Sirup Buah Naga Kulit Merah Daging Putih (Hylocereus undatus). Skripsi S-1 Universitas Sebelas Maret, Solo. 2010.

[20] Buckle, K.A., R.A. Edwards., G.H. Fleet dan M. Wooton.. Ilmu Pangan Cetakan ke empat. Penerbit University Press. Jakarta. 2007. 